\title{
DETERMINAN STRUKTUR MODAL DALAM PERSPEKTIF PECKING ORDER THEORY PADA PERUSAHAAN SUB SEKTOR MAKANAN DAN MINUMAN YANG TERDAFTAR DI BEI
}

\author{
Siti Kholifah, Sumani, Novi Puspitasari \\ Fakultas Ekonomi dan Bisnis Universitas Jember, Jember
}

\begin{abstract}
Abstrak $\quad$ Penelitian ini bertujuan untuk menganalisis pengaruh ukuran perusahaan, risiko bisnis, pertumbuhan aset, dan profitabilitas terhadap struktur modal perusahaan, serta menganalisis penerapan Pecking Order Theory (POT) pada perusahaan. Populasi dalam penelitian ini adalah seluruh perusahaan sub sektor makanan dan minuman yang terdaftar di Bursa Efek Indonesia (BEI) periode tahun 2014-2016. Teknik pengambilan sampel yang digunakan adalah purposive sampling dengan sampel sebanyak 14 perusahaan. Data penelitian bersumber dari laporan keuangan perusahaan yang dipublikasikan di website BEI. Metode analisis yang digunakan adalah regresi linear berganda. Hasil penelitian menunujukan bahwa variabel profitabilitas terbukti berpengaruh signifikan terhadap struktur modal, sedangkan variabel ukuran perusahaan, risiko bisnis, dan pertumbuhan aset tidak berpengaruh terhadap struktur modal perusahaan. Untuk penerapan POT, pada tahun 2014 terdapat 6 perusahaan yang menerapkan POT, 7 perusahaan pada tahun 2015, dan 8 perusahaan pada tahun 2016.
\end{abstract}

Kata Kunci : Struktur modal, pecking order theory, perusahaan makanan dan minuman

\begin{tabular}{l|l} 
Abstract & $\begin{array}{l}\text { This study aims to analyze the effect of firm size, business risk, asset growth, and } \\
\text { profitability on capital structure and to examine the application of Pecking Order Theory } \\
\text { (POT) in the companies. The population was all food and beverage companies listed in } \\
\text { Indonesia Stock Exchange (IDX) in 2014-2016. This research used purposive sampling } \\
\text { technique with the sample consisted of 14 companies. Data were sourced from the company } \\
\text { financial reports published on IDX's website. Data were analyzed using multiple linear } \\
\text { regression. The results showed that profitability had a significant effect on capital } \\
\text { structure, while firm size, business risks, and asset growth did not affect the capital } \\
\text { structure of the firm. Related to the application of POT, the results showed that there were } 6 \\
\text { companies applying POT in 2014, } 7 \text { companies applying POT in 2015, and } 8 \text { companies } \\
\text { applying POT in 2016. }\end{array}$
\end{tabular}

Keywords : Capital structure, pecking order theory, food and beverage company

Fakultas Ekonomi dan Bisnis

Universitas Jember

E-mail : skholifah2018@gmail.com 


\section{Pendahuluan}

Indonesia merupakan negara dengan jumlah penduduk terbanyak ke 4 di dunia jumlah penduduk mencapai 253,60 juta jiwa. Tingkat konsumsi masyarakat pun ikut meningkat sehingga Indonesia menjadi target pasar produk-produk luar negeri yang potensial dan sebagai target investasi para investor asing, terutama pada sektor manufaktur. Industri sektor manufaktur memiliki pengaruh besar bagi perekonomian Indonesia, yang dapat dilihat dari besarnya sumbangan yang signifikan terhadap devisa negara melalui kegiatan ekspornya dan sumbangannya yang besar terhadap PDB Indonesia. Industri makanan dan minuman merupakan sub sektor yang memiliki kontribusi terbesar dalam pembangunan sektor industri terutama kontribusi terhadap Produk Domestik Bruto (PDB).

Kontribusi sektor manufaktur terhadap PDB nasional tercatat sebesar 20,92\% dan subsektor industri makanan dan minuman berkontribusi sebesar 34,42 persen dari subsektor lainnya (www.finance.detik.com). Tahun 2014, sektor industri makanan dan minuman berkontribusi sebesar 29,95\% terhadap PDB industri pengolahan non migas. Di samping itu, kontrbusi besar industri makanan dan minuman nasional terlihat dari sumbangan nilai ekspor yang terus naik mencapai USD456,6 juta pada Januari 2015 dibandingkan nilai ekspor pada januari 2014 sebesar USD 411,5 juta. Selanjutnya, perkembangan realisasi investasi sektor industri makanan dan minuman triwulan I tahun 2015 sebesar Rp. 6.167 miliar untuk PMDN dan PMA sebesar USD 533,8 juta (www.kemenperin.go.id). Pada tahun 2016, kontribusi industri makanan dan minuman terhadap Produk Domestik Bruto (PDB) juga terbilang yang tertinggi dibandingkan sektor industri lainnya yang mencapai 33,6 persen pada triwulan III tahun 2016. Sementara itu, sumbangan nilai ekspor produk makanan dan minuman termasuk minyak kelapa sawit pada Januari-September 2016 mencapai USD17,86 miliar. Capaian ini membuat neraca perdagangan masih positif bila dibandingkan dengan nilai impornya pada periode yang sama sebesar USD 6,81 miliar (http://www.kemenperin.go.id). Industri makanan dan minuman nasional mencatatkan pertumbuhan sebesar 7,19 persen pada triwulan II tahun 2017. Capaian tersebut turut beperan dalam kontribusi manufaktur andalan ini terhadap Produk Domestik Bruto (PDB) industri non-migas yang mencapai 34,17 persen atau tertinggi dibandingkan sektor lainnya (www.bisnis.rakyatku.com).

Hasil evaluasi menunjukan perekonomian Indonesia tahun 2013 menghadapi tantangan berat akibat dampak perlambatan ekonomi global, dan tahun 2014 merupakan tahun pemulihan dan stabilisasi ekonomi akibat fenomena kebangkrutan Lehman Brothers pada tahun 2008 serta krisis Eropa di Yunani pada tahun 2012 (www.kompasiana.com). Industri makanan dan minuan sendiri menghadapi sejumlah tantangan dan fenomena penting yang terjadi pada tahun 2014. Meskipun dihadapkan pada peluang meningkatnya konsumsi masyarakat karena penyelenggaraan Pemilu 2014, berbagai kebijakan dan kondisi perekonomian nasional yang menekan pertumbuhan sektor ini.

Tantangan yang dihadapi industri makanan dan minuman mulai dari nilai tukar rupiah yang melemah berdampak pada meningkatnya harga pokok produksi. Tercatat hingga akhir 2013, nilai melemah tajam menjadi Rp 12 ribu per dolar AS, dibandingkan awal 2013 yaitu Rp 9.500 per dolar AS. Selain itu, kenaikan Upah Minimum Propinsi (UMP) yang rata-rata mencapai $9 \%$ hingga $30 \%$ pada 2014 memaksa pelaku usaha melakukan penyesuaian pada komponen biaya produksi. Pada tahun 2014 ancaman kenaikan harga Tarif Dasar Listrik juga mempengaruhi industri makanan minuman (go public) yang berada dalam golongan I3 yang naik sekitar 38\%. Serta, kenaikan BI Rate hingga 7,5\% pada akhir 2013 menyebabkan naiknya suku bunga pinjaman (www.liputan6.com). Untuk itu, dibutuhkan strategi yang tepat untuk bersaing dengan para kompetitor. Salah satu yang perlu diperhatikan adalah bagaimana perusahaan menentukan struktur modal melalui keputusan pendanaan.

Penentuan struktur modal menjadi hal yang sangat penting bagi perusahaan. Hal ini berkaitan dengan kebutuhan modal perusahaan yang akan digunakan untuk 
membiayai operasional perusahaan demi tercapainya laba yang optimal. Manajer keuangan dihadapkan pada permasalahan tentang bagaimana menggunakan dana perusahaan melalui komposisi struktur modal yang tepat demi tercapainya laba yang diinginkan perusahaan. Selain mendapatkan laba, tujuan lain yang cukup penting adalah untuk menjaga kelangsungan hidup perusahaan terutama dalam menghadapi persaingan dari perusahaan yang sejenis, sehingga struktur modal berperan sangat penting dalam memaksimalkan nilai perusahaan.

Struktur modal berkaitan dengan penentuan komposisi modal perusahaan untuk keputusan pendanaan apakah akan menggunakan ekuitas atau utang untuk mendanai operasional perusahaan. Keputusan pendanaan disebut juga struktur modal berkaitan dengan pemilihan sumber pembiayaan baik yang berasal dari dalam maupun dari luar perusahaan. Sumber dana internal perusahaan berasal dari laba ditahan (retained earnings) dan depresiasi dana yang diperoleh dari sumber dana eksternal adalah dana yang berasal dari para kreditur dan stakeholder yang ikut dalam pengambil bagian dalam perusahaan. Keputusan pendanaan dapat diukur dengan Debt Equity Ratio (DER).

Banyak studi yang telah dilakukan berkaitan dengan struktur modal, baik itu untuk menguji faktor-faktor apa saja yang mempengaruhi struktur modal dan bagaimana struktur modal mempengaruhi nilai suatu perusahaan. Tidak ada jaminan mengenai kombinasi struktur modal yang jelas dan bagaimana komposisi modal yang tepat, namun pada dasarnya perusahaan harus berorientasi pada keberhasilan untuk menjaga kelangsungan hidup dan stabilitas finansial.

Penggunaan dana internal maupun eksternal memiliki implikasi yang berbeda bagi perusahaan. Manajer keuangan dihadapkan adanya variasi dalam pembelanjaan, yang terkadang perusahaan lebih baik menggunakan dana yang bersumber dari utang, maupun yang bersumber dari dana sendiri. Penggunaan utang dalam struktur modal dapat mencegah pengeluaran perusahaan yang tidak penting dan memberi dorongan manajemen untuk mengoperasikan perusahaan lebih efisien (Nuswandari, 2013).

Perusahaan yang mempunyai profit yang tinggi cenderung menggunakan sumber dana internal perusahaan bagi pembiayaannya, karena dinilai lebih murah dibandingkan jika perusahaan menggunakan sumber dana eksternal. Perusahaan akan memilih menggunakan sumber dana internal berupa laba ditahan, kemudian utang, dan yang terkahir adalah penerbitan saham. Hal tersebut yang disebut dengan Pecking order theory.

Penelitian mengenai struktur modal perusahaan dan teori Pecking Order sendiri telah dilakukan sejak puluhan tahun yang lalu, dimulai oleh Modigliani dan Miller pada tahun 1958. Berbagai penelitian pun terus dilakukan, baik itu di luar negeri maupun di Indonesia. Pada berbagai penelitian yang dilakukan, perusahaan manufaktur yang terdaftar di BEI menemukan adanya penerapan Pecking Order oleh perusahaan untuk keputusan pendanaan mereka. Variabel yang digunakan untuk menguji determinan struktur modal juga beragam. Profitabilitas, ukuran perusahaan, pertumbuhan asset, dan risiko bisnis adalah faktor-faktor yang dapat diteliti lebih lanjut pengaruhnya terhadap struktur modal. Hasil penelitian Setyawan dkk. (2008) dan Nuswandari (2013) mengemukakan bahwa profitabilitas dan ukuran perusahaan berpengaruh signifikan terhadap leverage (DER) perusahaan. Hal ini sejalan dengan pecking order theory, yaitu perusahaan yang memiliki profit tinggi lebih suka melakukan pembiayaan internal. Ukuran perusahaan juga menunjukkan bahwa perusahaan itu memiliki asset yang besar, begitu juga dengan keuntungan yang didapatkan. Hal ini berbanding terbalik dengan penelitian Restiyowati dkk. (2014) serta Mutamimah dan Rita (2009), dimana profitabilitas dan ukuran perusahaan berpengaruh negatif terhadap DER.

Risiko bisnis digunakan sebagai salah satu faktor penentu kebijakan struktur modal perusahaan. Penelitian yang dilakukan Nuswandari (2013) dan Restiyowati dkk. (2014) menemukan bahwa, risiko bisnis berpengaruh negatif terhadap DER. Studi lain 
yang dilakukan oleh Lestari (2015) juga mengungkapakan bahwa risiko bisnis tidak berpengaruh terhadap DER.

Tingkat pertumbuhan asset (asset growth), pertumbuhan aset perusahaan merupakan gambaran tentang perkembangan usaha yang dilakukan periode sekarang dibandingkan periode sebelumnya, yang penting untuk kebijakan struktur modal. Penelitian oleh Nuswandari (2013) serta Restiyowati dkk. (2014) menyimpulkan bahwa pertumbuhan asset berpengaruh positif terhadap DER. Perlu pertimbangan mengenai berbagai faktor yang mempengaruhi keputusan pendaan, serta teori-teori yang ada di dalamnya, agar keputusan manajer dalam menentukan struktur modal dapat meningkatkan keuntungan perusahaan, yang pada akhirnya akan memaksimalkan harga saham perusahaan demi kesejahteraan para stakeholder.

Berdasarkan uraian latar belakang, rumusan masalah dalam penelitian ini adalah apakah ukuran perusahaan, risiko bisnis, pertumbuhan aset, dan profitabilitas berpengaruh terhadap struktur modal, serta apakah perusahaan sub sektor makanan dan minuman yang menerapkan Pecking Order Theory dalam struktur modal. Penelitian ini bertujuan untuk menguji dan menganalisis pengaruh ukuran perusahaan, risiko bisnis, pertumbuhan aset, dan profitabilitas terhadap struktur modal, serta menganalisis penerapan Pecking Order Theory perusahaan sub sektor makanan dan minuman dalam struktur modal.

Terdapat empat hipotesis dalam penelitian ini. Pertama, Ukuran perusahaan berpengaruh terhadap struktur modal. Kedua, Risiko bisnis berpengaruh terhadap struktur modal. Ketiga, Pertumbuhan aset berpengaruh terhadap struktur modal. Keempat, Profitabilitas berpengaruh terhadap struktur modal.

\section{Metodologi}

Penelitian ini bersifat kuantitatif dan merupakan explanatory research dimana populasi dalam penelitian ini adalah seluruh perusahaan sub sektor makanan dan minuman yang terdaftar di BEI tahun 20142016. Jenis data yang digunakan dalam penelitian ini adalah data sekunder berupa laporan keuangan perusahaan sub sektor makanan dan minuman yang terdaftar di BEI pada tahun 2014-2016 yang diperoleh melalui website Bursa Efek Indonesia (www.idx.co.id). Sampel penelitian sebanyak 14 perusahaan.

Variabel yang digunakan berupa struktur modal sebagai variabel dependen, sedangkan variabel independen berupa ukuran perusahaan, risiko bisnis, pertumbuhan aset, dan profitabilitas.

\section{$\underline{\text { Struktur Modal }}$}

Variabel struktur modal diproksikan dengan DER. Menurut Brealy et. all (2001:76), DER merupakan rasio utang untuk mengukur tingkat pinjaman perusahaan yang dihitung dari perbandingan jumlah total liabilitas dibandingkan dengan jumlah total ekuitas. DER mencerminkan kemampuan suatu perusahaan dalam memenuhi kewajibannya. Semakin besar nilai DER, mencerminkan risiko perusahaan yang relatif tinggi, karena menunjukkan risiko kegagalan perusahaan untuk mengembalkan utang akan semakin tinggi, begitu juga sebaliknya. Struktur modal dinyatakan dalam bentuk skala rasio.

\section{$\underline{\text { Ukuran Perusahaan }}$}

Menurut Brigham dan Houston (2013: 117) ukuran perusahaan adalah rata-rata total penjualan bersih untuk tahun yang bersangkutan sampai beberapa tahun kemudian. Ukuran perusahaan yang merupakan ukuran atau besarnya asset yang dimiliki perusahaan ditunjukkan oleh natural logaritma dari total aktiva. Variabel ukuran perusahaan diproksikan dengan SIZE. Ukuran perusahaan dinyatakan dalam bentuk skala rasio.

\section{$\underline{\text { Risiko Bisnis }}$}

Risiko bisnis adalah ketidakpastian yang dihadapi perusahaan dalam menjalankan kegiatan bisnisnya. Risiko dalam hal ini adalah risiko bisnis (Business Risk) sebagai faktor penentu kebijakan struktur modal perusahaan, menggunakan standar deviasi dari laba sebelum bunga dan pajak atau Earnings Before Interest and Tax (EBIT) 
dibanding dengan total asset. Proxy ini diukur selama 3 tahun terakhir mulai periode (t-2) hingga periode $(\mathrm{t})$, Paramu (2006) dalam Indrajaya dkk. (2011). Risiko bisnis dinyatakan dalam bentuk skala rasio.

\section{$\underline{\text { Pertumbuhan Aset }}$}

Tingkat pertumbuhan aset perusahaan merupakan kemampuan perusahaan dalam meningkatkan asset perusahaan. Tingkat pertumbuhan asset (Asset Growth), dalam penelitian ini menggunakan persentase perubahan pada total aktiva dari tahun (t-1) terhadap tahun sekarang $(\mathrm{t})$, sebagai proxy (Weston dan Thomas, 2010: 66). Tingkat pertumbuhan aset dinyatakan dalam bentuk skala rasio.

\section{$\underline{\text { Profitabilitas }}$}

Profitabilitas adalah hasil bersih dari serangkaian kebijakan dan keputusan. Profitabilitas dapat ditetapkan dengan menghitung berbagai tolak ukur yang relevan. Salah satu tolak ukur tersebut adalah dengan rasio keuangan sebagai salah satu analisis dalam menganalisis kondisi keuangan, hasil operasi dan tingkat profitabilitas suatu perusahaan Brigham dan Houston (2013:107). Variabel profitabilitas diproksikan dengan ROA. Profitabilitas dinyatakan dalam bentuk skala rasio.

Analisi regresi linear berganda digunakan dalam penelitian ini untuk mengetahui pengaruh variabel-variabel independen terhadap variabel dependen, sedangkan untuk mengetahui penerapan Pecking Order Theory (POT) menggunakan Financing Deficit. Menurut Fama dan French (dalam Jumono dkk., 2013), untuk menghitung besar kecilnya Financing deficit yaitu:

$$
\text { FinDef }=\Delta \mathrm{NA}-\Delta \mathrm{RE}=\Delta \mathrm{LTD}+\mathrm{TE} \text {. }
$$

\section{Hasil dan Pembahasan}

\section{Hasil Analisis Regresi Linear Berganda}

Uji statistik $\mathrm{t}$ pada dasarnya menunjukkan seberapa jauh pengaruh satu variabel penjelas/independen secara individual dalam menerangkan variasi variabel dependen
(Ghozali, 2011:97). Tingkat signifikansi yang digunakan sebagai kriteria dalam penelitan ini adalah 5\%. Hipotesis diterima jika tingkat signifikansi kurang dari 5\% dan hipotesis ditolak jika tingkat signifikansi $5 \%$. Hasil uji t diterangkan pada Tabel 1:

Tabel 1. Uji t (Uji parsial)

\begin{tabular}{lccc}
\hline \multicolumn{1}{c}{ Variabel } & t & Signifikansi & Keterangan \\
\hline (Constant) & 2,248 & 0,196 & \\
\hline $\begin{array}{l}\text { Ukuran } \\
\text { Perusahaan }\end{array}$ & $\begin{array}{c}- \\
0,042\end{array}$ & 0,480 & $\begin{array}{c}\text { Tidak } \\
\text { signifikan }\end{array}$ \\
\hline Risiko Bisnis & $\begin{array}{c}\text { - } \\
2,849\end{array}$ & 0,394 & $\begin{array}{c}\text { Tidak } \\
\text { signifikan }\end{array}$ \\
\hline $\begin{array}{l}\text { Pertumbuhan } \\
\text { Aset }\end{array}$ & 0,108 & 0,869 & $\begin{array}{c}\text { Tidak } \\
\text { signifikan }\end{array}$ \\
\hline Profitabilitas & 0,969 & 0,041 & Signifikan \\
\hline Sumber:
\end{tabular}

Sumber: data sekunder, diolah

Berdasarkan hasil uji t pada Tabel 1, maka dapat disimpulkan sebagai berikut:

Variabel ukuran perusahaan memiliki koefisien sebesar $-0,042$ dan memiliki nilai signifikansi sebesar 0,480 , yang lebih besar dari tingkat signifikansi 0,05 . Sehingga dapat disimpulkan bahwa variabel ukuran perusahaan secara parsial tidak signifikan dan tidak memiliki pengaruh terhadap struktur modal. Dengan demikian berarti bahwa hipotesis 1 ditolak.

Variabel risiko bisnis memiliki koefisien sebesar -2,849 dan memiliki nilai signifikansi sebesar 0,394, yang lebih besar dari tingkat signifikansi 0,05. Sehingga dapat disimpulkan bahwa variabel risiko bisnis secara parsial tidak signifikan dan tidak memiliki pengaruh terhadap struktur modal. Dengan demikian berarti bahwa hipotesis 2 ditolak.

Variabel pertumbuhan aset memiliki koefisien sebesar 0,108 dan memiliki nilai signifikansi sebesar 0,869, yang lebih besar dari tingkat signifikansi 0,05. Sehingga dapat disimpulkan bahwa variabel ukuran perusahaan secara parsial tidak signifikan dan tidak memiliki pengaruh terhadap struktur modal. Dengan demikian berarti bahwa hipotesis 3 ditolak.

Variabel profitabilitas memiliki koefisien sebesar 0,969 dan memiliki nilai signifikansi sebesar 0,041, yang lebih kecil dari tingkat signifikansi 0,05. Sehingga dapat disimpulkan bahwa variabel profitabilitas secara parsial 
signifikan dan memiliki pengaruh terhadap struktur modal. Dengan demikian berarti bahwa hipotesis 4 diterima.

Pengujian Pecking Order Theory (POT)

Tabel 2. Hasil Uji Pecking Order Theory (POT)

\begin{tabular}{ccc}
\hline Tahun & $\begin{array}{c}\text { Jumlah } \\
\text { Penerapan } \\
\text { POT }\end{array}$ & Nama Perusahaan \\
\hline 2014 & 6 & $\begin{array}{c}\text { AISA, ALTO, DLTA, } \\
\text { ROTI, SKBM, STTP }\end{array}$ \\
\hline 2015 & 7 & $\begin{array}{c}\text { CEKA, DLTA, MLBI, } \\
\text { ROTI, SKBM, STTP, } \\
\text { ULTJ }\end{array}$ \\
\hline 2016 & 8 & $\begin{array}{l}\text { AISA, ALTO, CEKA, } \\
\text { MLBI, PSDN, ROTI, } \\
\text { SKLT, STTP }\end{array}$ \\
\hline Sumber: data sekunder,
\end{tabular}

Sumber: data sekunder, diolah

Pecking Order Theory (POT) menyatakan bahwa penentuan struktur modal yang optimal didasarkan pada keputusan pendanaan secara hierarki berdasarkan biaya modal paling murah yang bersumber pada sumber dana internal (Retained Earnings) sampai pada sumber dana eksternal (utang dan saham) (Jumono, 2013). Dari hasil deteksi dua tahap dengan menggunakan Financing Deficit, terdapat 6 perusahaan yang menerapkan POT pada tahun 2014, 7 perusahaan menerapkan POT pada tahun 2015, dan 8 perusahaan pada tahun 2016.

Terdapat 2 perusahaan yang menerapkan POT secara konsisten disetiap tahun pengamatan, yaitu PT. Nippon Indosari Corporindo Tbk. (ROTI) dan PT. Siantar Top Tbk. (STTP). Kondisi struktur modal perusahaan tersebut menunjukkan jumlah laba ditahan yang lebih besar dari jumlah utangnya. Hal ini mengindikasikan bahwa perusahaan tersebut menggunakan pembiayaan dari dana internal perusahaan untuk operasional.

Sebaliknya, terdapat 3 perusahaan yang tidak menerapkan POT sama sekali, yaitu PT. Indofood CBP Sukses Makmur Tbk. (ICBP), PT. Indofood Sukses Makmur Tbk. (INDF), dan PT. Mayora Indah Tbk. (MYOR). Kondisi struktur modal perusahaan-perusahaan tersebut menunjukkan tingginya tingkat utang perusahaan dibandingkan dengan jumlah dana internal perusahaan. Hal ini menunjukkan pendanaan operasional perusahaan yang dibiayai sebagian besar dari utangnya, sehingga perusahaan-perusahaan tersebut tidak menggunakan teori Pecking Order untuk pendanaannya.

\section{Kesimpulan}

Berdasarkan hasil penelitian untuk menjawab rumusan masalah, maka dihasilkan kesimpulan sebagai berikut, variabel ukuran perusahaan terbukti tidak berpengaruh signifikan terhadap struktur modal. Variabel risiko bisnis terbukti tidak berpengaruh signifikan terhadap struktur modal. Variabel pertumbuhan aset terbukti tidak berpengaruh signifikan terhadap struktur modal. Variabel profitabilitas terbukti berpengaruh signifikan terhadap struktur modal. Sebagian besar perusahaan sub sektor makanan dan minuman menerapkan Pecking Order Theory (POT) dalam struktur modal.

\section{Saran}

Berdasarkan hasil penelitian dan kesimpulan yang diuraikan di atas, maka dapat disampaikan bahwa, bagi pihak manajemen perusahaan sebaiknya sebelum menetapkan kebijakan struktur modalnya agar terlebih dahulu memperhatikan variabel profitabilitas, ukuran perusahaan, risiko bisnis, dan pertumbuhan aset, serta faktor-faktor lain yang memiliki pengaruh terhadap struktur modal, sehingga perusahaan dapat memutuskan kebijakan struktur modal yang baik bagi perusahaan. Bagi investor perlu memperhatikan nilai struktur modal perusahaan dengan tetap memperhatikan dampak positif maupun negatif. Dalam hal ini pihak investor perlu mencermati stuktur modal yang dimiliki perusahaan serta pemanfaatanya agar modal yang dimili perusahaan dapat memiliki komposisi yang optimal dengan kemampuan dan tingkat pertumbuhan perusahaan. Bagi peneliti selanjutnya, diharapkan dapan meneliti variabel-variabel lain yang dapat mempengaruhi struktur modal, dan menambah jumlah sampel maupun periode penelitian sehingga model regresi yang dihasilkan semakin mencerminkan hubungan regresi yang diuji. 


\section{Daftar Referensi}

Andi Chaerul Fadli. 2017. http://bisnis.rakyatku.com/read/60768/20 17/08/13/kontribusi-industri-makananminuman-34-17-terhadap-pertumbuhanekonomi. Diakses tanggal 26 Januari 2018.

Ardan Adhi Chandra. 2017.https://finance.detik.com/beritaekonomi-bisnis/3406077/industrimakanan-dan-minuman-ri-sumbang-pdbrp-540-triliun. Diakses tanggal 26 Januari 2018.

Brigham, Eugene F., dan Houston, Joel F. 2013. Dasar-Dasar Manajemen Keuangan. Jakarta: Salemba Empat

Dewi Wiwiek. 2015.

https://www.kompasiana.com/dewi.wiwiek $\angle$ sekilas-ekonomi-indonesia2014_552ff8596ea83405778b462c. Diakses tanggal 2 Mei 2018.

Ghozali, Imam. 2011. Aplikasi Analisis Multivariate dengan Program IBM SPSS 2. Edisi 8. Semarang: Universitas Diponegoro.

Indrajaya dkk. 2011. Pengaruh Struktur Aktiva, Ukuran Perusahaan, Tingkat Pertumbuhan, Profitabilitas, dan Risiko Bisnis Terhadap Struktur Modal: Studi Empiris pada Perusahaan Sektor Pertambangan yang Listing di Bursa Efek Indonesia Periode 2004-2007. Akurat Jurnal Ilmiah Akuntansi

Lestari, Sigita. 2015. "Determinan Struktur Modal dalam Perspektif Pecking Order Theory dan Agency Theory". Jurnal WRA. Vol. 3, No. 1

Mutamimah dan Rita. 2009. "Keputusan Pendanaan: Pendekatan Trade-Off Theory dan Pecking Order Theory". Jurnal Ekonomi dan Bisnis. Vol. 10, No. 1

Nuswandari, Cahyani. 2013. "Determinan Struktur Modal dalam Perspektif Pecking Order Theory dan Agency Theory". Jurnal Dinamika Akuntansi, Keuangan dan Perbankan. Vol. 2, No. 1

Restiyowati, I., dan Widyawati, N. 2014. "FaktorFaktor yang Mempengaruhi Struktur Modal Perusahaan Property di Bursa Efek Indonesia". Jurnal Ilmu \& Riset Manajemen. Vol. 3, No. 2
Septian

Deny. 2014. https://www.liputan6.com/bisnis/read/20 50181/4-hal-yang-memukul-industrimakanan-minuman-ri. Diakses tanggal $2 \mathrm{Mei}$ 2018.

Weston, J.F \& Brigham, E.F. 2010. Essentials of Managerial Finance. Seventh Edition.USA: Holt Rineholt and Winston.Terjemahan Drs. A.Q. Khalid.1991. Dasar-Dasar Manajemen Keuangan. Edisi Ketujuh. Jilid 2. Jakarta: Erlangga

www.idx.co.id. Diakses tanggal 3 Desember 2017.

2016.

http://www.kemenperin.go.id/artikel/1665

$0 /$ Industri-Makanan-dan-MinumanTumbuh-9,8-Persen-Triwulan-III-2016. Diakses tanggal 26 Januari 2018. 